\title{
Experimental and Theoretical Studies of Diatomic Gold Halides
}

\author{
J. Reuben Brown and Peter Schwerdtfeger \\ Department of Chemistry, University of Auckland, Auckland, New Zealand \\ Detlef Schröder and Helmut Schwarz \\ Institut für Chemie der Technischen Universität Berlin, Berlin, Germany
}

\begin{abstract}
The diatomic gold halides AuX are studied by means of Fourier-transform ion cyclotron resonance mass spectroscopy and ab initio theory at a quasi-relativistic CCSD(T) level of theory. A thermokinetic approach is used to determine the bond-dissociation energies of neutral $\mathrm{AuCl}, \mathrm{AuBr}$, and $\mathrm{AuI}$ as well as cationic $\mathrm{AuI}^{+}$, i.e., $D_{0}(\mathrm{Au}-\mathrm{Cl})=66 \pm 3 \mathrm{kcal} / \mathrm{mol}$, $D_{0}(\mathrm{Au}-\mathrm{Br})=50 \pm 5 \mathrm{kcal} / \mathrm{mol}$, as well as the brackets $52 \mathrm{kcal} / \mathrm{mol}<D_{0}(\mathrm{Au}-\mathrm{I})<64 \mathrm{kcal} / \mathrm{mol}$ and $54 \mathrm{kcal} / \mathrm{mol}<D_{0}\left(\mathrm{Au}^{+}-\mathrm{I}\right)<66 \mathrm{kcal} / \mathrm{mol}$ at $0 \mathrm{~K}$. These values allow an evaluation of previous experimental and theoretical data concerning diatomic gold halides. (J Am Soc Mass Spectrom 2002, 13, 485-492) (C) 2002 American Society for Mass Spectrometry
\end{abstract}

$\mathrm{T}$ The properties of diatomic gold halides $\mathrm{AuX}(\mathrm{X}=$ $\mathrm{F}-\mathrm{I}$ ) have been subject of numerous theoretical investigations because gold bears a local maximum of relativistic effects, thereby providing a benchmark to test relativistic techniques in quantum chemistry [1]. The experimental characterization of the gaseous gold halides is more difficult [2], however, and only recently decisive experimental measurements of some spectroscopic properties of $\mathrm{AuF}$ [3, 4], $\mathrm{AuCl}$ [5-7], $\mathrm{AuBr}$ [5], and AuI [8] have been published. As far as experimental determinations of the bond dissociation energies $(B D E s)$ of $\mathrm{AuX}$ diatomics are concerned, only some extrapolations from spectroscopy $[6,8]$ and a few ion/ molecule bracketing data are available $[9,10]$. In marked contrast, numerous theoretical studies appeared on these species [11-17]. However, also the theoretical predictions show a considerable spread (Table 1).

In this study, Fourier-Transform mass spectrometry is used to perform experiments aimed at a determination of the BDEs of the neutral and cationic diatomic gold halides. These experimental studies are complemented by ab initio calculations employing the coupled cluster method as well as density functional theory (DFT).

Published online March 27, 2002

Dedicated to our friend and cooperation partner Peter B. Armentrout.

Address reprint requests to Dr. Detlef Schröder, Institut für Chemie der Technischen Universität Berlin, Straße des 17. Juni 135, Berlin D-10623, Germany. E-mail: detlef.schroder@ochssrv-01-1.chem.tu.berlin.de

\section{Experimental Details}

All experiments were performed using a Spectrospin CMS 47X Fourier Transform ion cyclotron (FTICR) spectrometer, described in more detail elsewhere [18]. In brief, $\mathrm{Au}^{+}$cations were generated by laser desorption/ionization of a gold target and transferred by an array of electric focusing lenses to the FTICR cell situated in a 7 Tesla magnetic field. Then, $\mathrm{Au}^{+}$was thermalized with pulsed-in argon gas, mass-selected, and reacted with the neutral reagents as indicated below at typical pressures between $10^{-9}$ and $10^{-8}$ mbar. Unless mentioned otherwise, all reactions described here followed pseudo-first order kinetics. In the determination of reaction rate constants $\left(k_{r}\right)$, the respective ion-gauge sensitivities [19] as well as calibration factors [20] were considered. Gas-kinetic collision rates $\left(k_{c}\right)$ were derived from the capture theory [21], and used to evaluate the associated reaction efficiencies defined as $\phi=k_{r} / k_{c}$. Explicit kinetic modeling of the $\mathrm{Au}^{+} /$ $\mathrm{CH}_{3} \mathrm{Cl}$ system was performed by an iterative processing of the underlying kinetic equations with the condition $k_{r} \leq k_{c}$ as the only restriction.

\section{Computational Details}

$\mathrm{Ab}$ initio calculations were performed using the Gaussian 98 program [22] at the $\operatorname{CCSD}(\mathrm{T})$ level. For gold, the basis set adjusted by Schwerdtfeger et al. [23] was contracted to give a $(311111111 / 3111111 / 41111 / 111)$ set (starting from the functions with the highest exponent in each basis-type) and used with a Stuttgart pseudo-potential [24] which comprises a $[\mathrm{Kr}] 4 \mathrm{~d}^{10} 4 \mathrm{f}^{14}$ 
Table 1. Literature values of experimental and theoretical BDEs (in $\mathrm{kcal} / \mathrm{mol}$ ) of diatomic AuX species

\begin{tabular}{lll}
\hline & \multicolumn{1}{c}{ Experimental } & Theory $^{\mathrm{a}}$ \\
\hline \hline $\mathrm{AuF}$ & $73[10]^{\mathrm{b}}$ & $67[14], 71[12], 76[15], 77[15]$ \\
$\mathrm{AuF}^{+}$ & $>60[9]^{\mathrm{b}}, 72[6]^{\mathrm{c}} 78[5]^{\mathrm{cd}}$ & $18[12]$ \\
$\mathrm{AuCl}$ & $>36[9]^{\mathrm{b}}, 68[6]^{\mathrm{c}}$ & $58[16]$ \\
$\mathrm{AuBr}$ & $66[8]^{\mathrm{c}}$ & $53[16]$ \\
$\mathrm{Aul}$ & $>56[9]^{\mathrm{b}}$ & $48[44], 49[16]$ \\
$\mathrm{Aul}^{+}$ & $>$
\end{tabular}

a"Best" levels chosen and converted to $D_{O}$ at $0 \mathrm{~K}$.

balue obtained from bracketing experiments conducted at room temperature without acknowledging thermal effects, see text.

${ }^{\mathrm{c}}$ Derived from microwave spectroscopy.

dDerived in ref. [6] from the data in ref. [5].

core and $5 s^{2} 5 p^{6} 5 d^{10} 6 s^{1}$ valence space. For fluorine and chlorine, the augmented, correlation-consistent triple zeta basis sets of Dunning $[25,26]$ were used with the most diffuse f-functions removed. For bromine and iodine, the Stuttgart pseudopotential combinations were altered to give $(211111 / 21111 / 11 / 1)$ and (2111111/1111111/11/1) sets for $\mathrm{Br}$ and I, respectively, with basis sets, pseudopotentials, and extra $\mathrm{d}$ - and $\mathrm{f}$ functions taken from refs. [16], [27], and [28]. In the course of these studies, also some calculations at the MP 2 level were performed including Mulliken population analysis.

Potential energy curves were calculated at $r_{e}$ and $r_{e}=$ $\pm 0.05, \pm 0.1, \pm 0.15, \pm 0.2, \pm 0.3, \pm 0.35, \pm 0.5$ and +1.0 and $+1.5 \AA$. Rovibrational constants were derived using the numerical Numerov-Cooley procedure as implemented in Molcas3 [29]. Dissociation energies were calculated relative to the energies of the separated atoms. For AuX neutrals, spin-orbit corrections of the dissociation energies were derived from the atomic spin-orbit splittings of the Group 17 atoms [30].

In order to estimate thermal contributions to the experimental reaction energies, DFT calculations were performed initially using the SDD basis set for all atoms, as implemented in Gaussian 98. The calculations were then repeated using $6-311+\mathrm{G}^{*}$ basis sets on all atoms, except for $\mathrm{Au}, \mathrm{Br}$, and I (SDD-aug) where two extra d-functions were added to $\mathrm{Br}$ and $\mathrm{I}$ in order to mimic a $6-311+G^{*}$ set. These calculations were performed with complete geometry optimizations and frequency analysis with the B3LYP functional as implemented in Gaussian 98.

\section{Results}

In this paper, we apply the thermokinetic method developed by Bouchoux and coworkers [31] to investigate the thermochemistry of the diatomic gold halides $\mathrm{AuX}$ and their cations. To this end, halide abstractions by the gold cation $\mathrm{Au}^{+}$from various halides $\mathrm{R}-\mathrm{X}$ are monitored by means of Fourier-Transform mass spectrometry. From an heuristic point of view, it is worth to note that the choice of the reactants used in the experiments was guided by the computational results which also assist the interpretation of the measurements.

\section{Computed properties of neutral and cationic AuX diatoms}

Table 2 displays some properties of neutral $\mathrm{AuX}$ and of the corresponding $\mathrm{AuX}^{+}$cations for $\mathrm{X}=\mathrm{F}-\mathrm{I}$ as computed at the $\operatorname{CCSD}(\mathrm{T})$ level of theory. While we do not want to overrate the accuracy of the absolute $B D E s$ computed at this level of theory, some qualitative conclusions can be drawn and particularly the relative trends appear reliable. Thus, the neutral gold(I) halides behave as expected for metal halides in that $D_{0}(\mathrm{Au}-\mathrm{X})$ decreases monotonically from $\mathrm{X}=\mathrm{F}$ to $\mathrm{X}=\mathrm{I}$ concomitant with increasing bond lengths and decreasing vibrational frequencies. As expected, the bonding of the neutral gold halides can be described as a mixture of ionic and covalent contributions, which is reflected by the trend of the positive charge on gold according to population analysis, i.e., $q_{A u}=0.70$ in $\mathrm{AuF}, 0.48$ in $\mathrm{AuCl}, 0.30$ in AuBr, and 0.27 in AuI.

In marked contrast, the $B D E s$ of the cationic species strongly rise from only $20.7 \mathrm{kcal} / \mathrm{mol}$ for $\mathrm{AuF}^{+}$to 50.6 $\mathrm{kcal} / \mathrm{mol}$ in the case of $\mathrm{AuI}^{+}$. To a first approximation, this unusual behavior can be ascribed to the valence configuration of the $\mathrm{Au}^{+}$cation which bears a quasiclosed $6 \mathrm{~s}^{2} 5 \mathrm{~d}^{10}$ shell. Thus, covalent binding to the halide radical would require excitation to the $6 \mathrm{p}$-manifold which is very unfavorable energetically. Consequently, the bonding situation in $\mathrm{AuX}^{+}$is best described as the interaction of a $\mathrm{Au}^{+}$cation with a halide radical $\left(\mathrm{Au}^{+\cdots} \mathrm{X}\right)$. Such a type of bonding is governed by ion/induced-dipole and charge-transfer interactions (both $\mathrm{Au}^{2+\cdots} \mathrm{X}^{-}$and $\mathrm{Au} \cdots \mathrm{X}^{+}$) leading to the strongest

Table 2. Properties of neutral and cationic gold halides calculated at the $\operatorname{CCSD}(\mathrm{T})$ level of theory

\begin{tabular}{lcccc}
\hline & AuF & $\mathrm{AuCl}$ & $\mathrm{AuBr}$ & Aul \\
\hline \hline$r_{e}(\AA ̊)$ & 1.930 & 2.226 & 2.339 & 2.506 \\
$D_{o}(\mathrm{kcal} / \mathrm{mol})$ & 62.0 & 58.9 & 51.0 & 43.4 \\
$\omega_{e}\left(\mathrm{~cm}^{-1}\right)$ & 550.8 & 372.7 & 260.6 & 208.7 \\
& & & & \\
$r_{e}(\AA)$ & $\mathrm{AuF}^{+}$ & $\mathrm{AuCl}^{+}$ & $\mathrm{AuBr}^{+}$ & $\mathrm{Aul}^{+}$ \\
$D_{o}(\mathrm{kcal} / \mathrm{mol})$ & 1.867 & 2.226 & 2.351 & 2.521 \\
$\omega_{e}\left(\mathrm{~cm}^{-1}\right)$ & 20.7 & 31.2 & 40.7 & 50.7 \\
\hline
\end{tabular}


bond for the largest, least electronegative halogen iodine. Nevertheless, it is interesting to note that despite of the weaker bonding, the fundamental frequency of $\mathrm{AuF}^{+}$exceeds that of the neutral counterpart, pointing to notable covalent contributions to the bonding of the $\mathrm{AuX}^{+}$cations. Notwithstanding, the electrostatic description as $\mathrm{Au}^{+} \mathrm{X}^{\cdots}$ is chemically insightful and can directly explain the unusual trend of the bond strengths in the $\mathrm{AuX}^{+}$cations for $\mathrm{X}=\mathrm{F}-\mathrm{I}$. This bonding mnemonic is further supported by population analysis which reveals that the spin density in $\mathrm{AuX}^{+}$is mostly located on the halogens, i.e., $\rho_{X}=0.88$ in $\mathrm{AuF}^{+}, 0.93$ in $\mathrm{AuCl}^{+}, 0.92$ in $\mathrm{AuBr}^{+}$, and 1.02 in $\mathrm{AuI}^{+}$, respectively.

In addition, the ionization energies of diatomic $\mathrm{AuX}$ species are calculated as $I E(\mathrm{AuF})=11.05 \mathrm{eV}, I E(\mathrm{AuCl})$ $=10.39 \mathrm{eV}, I E(\mathrm{AuBr})=9.82 \mathrm{eV}$, and $I E(\mathrm{AuI})=9.18 \mathrm{eV}$, respectively, at this level of theory. Note, however, that the computed $\operatorname{IE}(\mathrm{Au})=8.95 \mathrm{eV}$ is underestimated at this level in comparison to the experimental value of $I E(\mathrm{Au})=9.2255 \mathrm{eV}[32]$.

With regard to the experimental studies, the computational results imply that except of $\mathrm{AuI}^{+}$(see below), $\mathrm{AuX}^{+}$cations are unlikely to be formed via X-abstraction from any substrate $\mathrm{R}-\mathrm{X}$ by $\mathrm{Au}^{+}$under thermal conditions. For example, even $D(\mathrm{Br}-\mathrm{Br})=51 \mathrm{kcal} / \mathrm{mol}$ is too large to allow for the formation of $\mathrm{AuBr}^{+}$; hence, this reaction was not examined for obvious reasons. Further, the formation of $\mathrm{AuX}^{+}$is unfavorable because the $I E$ of the remaining radical $\mathrm{R}^{\circ}$ is likely to be lower than the computed IE( $\mathrm{AuX})$. Accordingly, the formation of neutral AuX concomitant with $\mathrm{R}^{+}$is expected and indeed observed experimentally (see below). Of course, $\mathrm{AuX}^{+}$cations with $\mathrm{X}=\mathrm{F}-\mathrm{Br}$ can be formed under more energetic conditions, such as electron ionization of gaseous gold halides [9, 33-35].

\section{Experimental Results}

In 1994, bracketing methods predicted $B D E(A u-F) \approx 73$ $\mathrm{kcal} / \mathrm{mol}$ [10] which is in excellent agreement with computational predictions $\left(D_{0}=70.7 \mathrm{kcal} / \mathrm{mol}\right.$ [12]). While we originally intended to measure all four gold halides, a lack of suitable new substrates prevented any further work on AuF, beyond that done already. We note in passing, however, that the speculation of Saenger and Sun [36] that $\mathrm{AuF}^{+}$might contribute to their reported AuF spectrum can be ruled out, because the computed fundamental vibrations differ largely (Table 2).

Therefore, we concentrate on the higher gold halides with $\mathrm{X}=\mathrm{Cl}, \mathrm{Br}$, and I. Qualitative information on these species is available from the early studies of Chowdhury and Wilkins [9] who examined the reactions of $\mathrm{Au}^{+}$with some haloalkanes (see Table 1). Here, we intend to refine and extend these studies by appropriate choice of the substrates in conjunction with application of thermokinetic criteria.
$\mathrm{AuCl}$. Mass-selected, thermalized $\mathrm{Au}^{+}$was reacted with various chlorine-containing substrates (Table 3). Formation of the corresponding carbocations concomitant with neutral $\mathrm{AuCl}$ prevails in most cases. For chlorobenzene, electron transfer is observed to predominate which is trivial, however, because $I E\left(\mathrm{C}_{6} \mathrm{H}_{5} \mathrm{Cl}\right)=$ $9.07 \mathrm{eV}[38]$ is significantly smaller than $\operatorname{IE}(\mathrm{Au})=9.2255$ $\mathrm{eV}$ [37]. Formation of cationic gold compounds is only observed for $\mathrm{CH}_{3} \mathrm{Cl}$ and $\mathrm{CH}_{2} \mathrm{Cl}_{2}$ which afford the corresponding gold-carbene cations $\mathrm{AuCH}_{2}^{+}[9,38]$ and $\mathrm{AuCHCl}^{+}$, respectively, concomitant with losses of neutral $\mathrm{HCl}$.

In order to apply the thermokinetic method of Bouchoux and coworkers [31], the chloride abstraction reaction (eq 1) is considered in more detail.

$$
\mathrm{Au}^{+}+\mathrm{R}-\mathrm{Cl} \rightarrow \mathrm{AuCl}+\mathrm{R}^{+}
$$

Under thermal conditions, the energetics of the lefthand side of eq 1 are given by the sum of the heats of formation $\Delta_{f} H\left(\mathrm{Au}^{+}\right)$and $\Delta_{f} H(\mathrm{R}-\mathrm{Cl})$, while the righthand side is given by the sum of $\Delta_{f} H(\mathrm{AuCl})$ and $\Delta_{f} H\left(\mathrm{R}^{+}\right)$, where all values except $\Delta_{f} H(\mathrm{AuCl})$ are available in ref. [37]. In the thermokinetic method, it is assumed that a very exothermic reactions occurs at collision rate while a very endothermic process is unmeasurably slow. In the intermediate range close to thermoneutrality, a sigmoid function of the type $\phi_{\text {rel }}=$ $\mathrm{a} /[1+\exp (\mathrm{b} \cdot(\Delta E-\mathrm{c}))]$ can be used to describe the energy dependence of $\phi$, where $\phi_{\text {rel }}$ is the normalized reaction efficiency, $\Delta E$ includes thermochemical quantities of the species involved, and a - c are variable parameters of which a is a scaling factor, $b$ describes the slope of the sigmoid curve, and c shifts the position of the onset [31]. In the present case, $\Delta E$ is chosen such that c corresponds to $B D E(\mathrm{Au}-\mathrm{Cl})$. Applying this scheme to the reactions shown in Table 3 for $X=C l$, a graph is obtained (Figure 1) from which $B D E(\mathrm{Au}-\mathrm{Cl})=69 \pm 2$ $\mathrm{kcal} / \mathrm{mol}$ can be derived (parameters: $\mathrm{a}=0.95, \mathrm{~b}=0.53$ $\mathrm{mol} / \mathrm{kcal}, \mathrm{c}=B D E=69.3 \mathrm{kcal} / \mathrm{mol}$ ).

So far, we deliberately used the somewhat vague term $B D E$ instead of $D_{0}, D_{298}$ etc. This is done because processes such as eq 1 which involve an atomic species on only one side of the equation bear non-negligible thermal contributions $\Delta E_{\text {thermal }}$ which favor the righthand side of eq 1 provided that also $\mathrm{R}$ is polyatomic. With respect to the specific set of reactions considered here, these thermal corrections were calculated using the B3LYP approach. These contributions, defined as $\Delta E_{\text {thermal }}=E_{0 K}-G_{298 K}$, are also included in Table 2. On average, $\Delta E_{\text {thermal }}$ amounts to $3 \pm 1 \mathrm{kcal} / \mathrm{mol}$ [39], and accordingly, we arrive at $D_{0}(\mathrm{Au}-\mathrm{Cl})=66 \pm 3 \mathrm{kcal} / \mathrm{mol}$ at $0 \mathrm{~K}$.

$A u B r$. Application of the same strategy for various bromine compounds (Table 3) is somewhat less straightforward, because we have not found suitable substrates which show intermediate reactivity. Either, 
Table 3. Efficiencies $(\phi \text { in } \%)^{a}$ and products ${ }^{\mathrm{b}}$ in the reactions of several chlorine- and bromine-containing molecules $\mathrm{R}-\mathrm{X}(\mathrm{X}=\mathrm{Cl}$, $\mathrm{Br}$ ) with Mass-selected $\mathrm{Au}^{+}$cations

\begin{tabular}{|c|c|c|c|c|c|c|}
\hline & $\Delta_{f} H(\mathrm{R}-\mathrm{X})^{\mathrm{c}}$ & $\phi$ & Products & $\mathrm{BR}^{\mathrm{b}}$ & $\Delta_{f} H\left(\mathrm{R}^{+}\right)^{\mathrm{c}}$ & $\Delta E_{\text {thermal }}{ }^{\mathrm{d}}$ \\
\hline $\mathrm{CH}_{3} \mathrm{Cl}^{\mathrm{e}}$ & -17.5 & 31 & $\begin{array}{l}\mathrm{AuCl}+\mathrm{CH}_{3}^{+} \\
\mathrm{AuCH}_{2}^{+}+\mathrm{HCl}^{+} \\
\mathrm{AuH}+\mathrm{CH}_{2} \mathrm{Cl}^{+}\end{array}$ & $\begin{array}{l}(0.00) \\
(0.95) \\
(0.05)\end{array}$ & $\begin{array}{l}261 \\
229\end{array}$ & -1.3 \\
\hline $\mathrm{CH}_{2} \mathrm{Cl}_{2}$ & -22.9 & 50 & $\begin{array}{l}\mathrm{AuCHCl}++\mathrm{HCl} \\
\mathrm{AuCl}+\mathrm{CH}_{2} \mathrm{Cl}^{+}\end{array}$ & $\begin{array}{l}(0.20) \\
(0.80)\end{array}$ & 229 & -2.4 \\
\hline $\begin{array}{l}\mathrm{CHCl}_{3} \\
\mathrm{CCl}_{4}\end{array}$ & $\begin{array}{l}-25.0 \\
-23.2\end{array}$ & $\begin{array}{l}77 \\
74\end{array}$ & $\begin{array}{l}\mathrm{AuCl}+\mathrm{CHCl}_{2}^{+} \\
\mathrm{AuCl}+\mathrm{CCl}_{3}^{+}\end{array}$ & $\begin{array}{l}(1.00) \\
(1.00)\end{array}$ & $\begin{array}{l}212 \\
199\end{array}$ & $\begin{array}{l}-4.7 \\
-3.4\end{array}$ \\
\hline $\mathrm{CF}_{2} \mathrm{Cl}_{2}$ & -114.1 & 72 & $\mathrm{AuCl}+\mathrm{CF}_{2} \mathrm{Cl}^{+}$ & $(1.00)$ & 126 & -3.3 \\
\hline$i-\mathrm{C}_{3} \mathrm{H}_{7} \mathrm{Cl}$ & -34.6 & 69 & $\begin{array}{l}\mathrm{AuCl}+\mathrm{C}_{3} \mathrm{H}_{7}^{+} \\
\mathrm{H}_{2} / \mathrm{AuCl}+\mathrm{C}_{3} \mathrm{H}_{5}^{+}\end{array}$ & $\begin{array}{l}(0.94) \\
(0.06)^{\mathrm{e}}\end{array}$ & 191 & -2.9 \\
\hline $\mathrm{C}_{6} \mathrm{H}_{5} \mathrm{Cl}$ & 13.0 & 86 & $\begin{array}{l}\mathrm{AuCl}+\mathrm{C}_{6} \mathrm{H}_{5}^{+} \\
\mathrm{Au}+\mathrm{C}_{6} \mathrm{H}_{5} \mathrm{Cl}^{+}\end{array}$ & $\begin{array}{l}(0.10) \\
(0.90)\end{array}$ & 269 & -3.8 \\
\hline $\mathrm{CH}_{3} \mathrm{Br}^{\mathrm{fg}}$ & -5.5 & 10 & $\begin{array}{l}\mathrm{AuBr}+\mathrm{CH}_{3}^{+} \\
\mathrm{AuCH}_{2}^{+}+\mathrm{HBr}\end{array}$ & $\begin{array}{l}(0.00) \\
(1.00)\end{array}$ & 261 & -1.2 \\
\hline $\mathrm{CH}_{2} \mathrm{Br}_{2}$ & 0 & 87 & $\mathrm{AuBr}+\mathrm{CH}_{2} \mathrm{Br}^{+}$ & $(1.00)$ & 224 & -2.4 \\
\hline $\mathrm{CHBr}_{3}$ & 5.7 & 92 & $\mathrm{AuBr}+\mathrm{CHBr}_{2}^{+}$ & $(1.00)$ & 224 & -3.6 \\
\hline $\mathrm{CF}_{3} \mathrm{Br}$ & -155 & $<1^{h}$ & $\mathrm{AuBr}+\mathrm{CF}_{3}{ }^{+}$ & $(1.00)^{\mathrm{h}}$ & 95 & -3.2 \\
\hline $\mathrm{C}_{2} \mathrm{H}_{5} \mathrm{Br}$ & -14.9 & 74 & $\begin{array}{l}\mathrm{Au}(\mathrm{HBr})^{+}+\mathrm{C}_{2} \mathrm{H}_{4} \\
\mathrm{Au}\left(\mathrm{C}_{2} \mathrm{H}_{4}\right)^{+}+\mathrm{HBr} \\
\mathrm{AuBr}+\mathrm{C}_{2} \mathrm{H}_{5}+\end{array}$ & $\begin{array}{l}(0.20) \\
(0.45) \\
(0.35)\end{array}$ & 216 & -2.4 \\
\hline $\mathrm{C}_{3} \mathrm{H}_{5} \mathrm{Br}^{\mathrm{i}}$ & 11.4 & 77 & $\begin{array}{l}\mathrm{AuBr}+\mathrm{C}_{3} \mathrm{H}_{5}{ }^{+} \\
\mathrm{H}_{2} / \mathrm{AuBr}+\mathrm{C}_{3} \mathrm{H}_{3}{ }^{+}\end{array}$ & $\begin{array}{l}(0.85) \\
(0.15)^{\mathrm{e}}\end{array}$ & 226 & -2.6 \\
\hline$t-\mathrm{C}_{4} \mathrm{H}_{9} \mathrm{Br}$ & -32 & 84 & $\begin{array}{l}\mathrm{AuBr}+\mathrm{C}_{4} \mathrm{H}_{9}^{+} \\
\mathrm{H}_{2} / \mathrm{AuBr}+\mathrm{C}_{4} \mathrm{H}_{7}^{+}\end{array}$ & $\begin{array}{l}(0.87) \\
(0.13)^{\mathrm{e}}\end{array}$ & 166 & -4.6 \\
\hline $\mathrm{C}_{6} \mathrm{H}_{5} \mathrm{Br}$ & 24.9 & 44 & $\begin{array}{l}\mathrm{AuBr}+\mathrm{C}_{6} \mathrm{H}_{5}^{+} \\
\mathrm{Au}+\mathrm{C}_{6} \mathrm{H}_{5} \mathrm{Br}^{+}\end{array}$ & $\begin{array}{l}(0.18) \\
(0.82)\end{array}$ & 269 & -3.8 \\
\hline
\end{tabular}

a Given as $\phi=k_{r} / k_{c}$ with an estimated error of \pm 30

branching ratios given in brackets.

'Heats of formation at $298 \mathrm{~K}$ taken from Ref. [37].

d Terms used to correct $298 \mathrm{~K}$ to $0 \mathrm{~K}$ values defined as $\Delta E_{\text {thermal }}=\Delta_{r} G_{298}-\Delta_{r} H_{O}$ determined by B3LYP calculations

eNature of the neutral product(s) is unclear.

fWhile the $\left[\mathrm{Au}, \mathrm{C}, \mathrm{H}_{3} \mathrm{X}\right]^{+}$products reported in Ref. [9] were also observed in our studies, these are entirely due to consecutive reactions, see text. gproduct distributions similar to those reported in Ref. [9] are observed when thermalization of Au ${ }^{+}$by pulsed-in argon buffer gas is omitted.

${ }^{h}$ Only observed when thermalization of $\mathrm{Au}^{+}$by pulsed-in argon buffer gas is omitted.

iAllyl bromide.

bromide abstraction occurs very fast $\left(\mathrm{R}=\mathrm{CH}_{2} \mathrm{Br}\right.$, $\left.\mathrm{CHBr}_{2}, \mathrm{C}_{3} \mathrm{H}_{5}, t-\mathrm{C}_{4} \mathrm{H}_{9}\right)$ or it is rather slow $\left(\mathrm{R}=\mathrm{C}_{6} \mathrm{H}_{5}\right)$, if not absent $\left(\mathrm{R}=\mathrm{CH}_{3}, \mathrm{CF}_{3}\right)$. While halide abstraction occurs to only $35 \%$ with bromoethane $\left(\mathrm{R}=\mathrm{C}_{2} \mathrm{H}_{5}\right)$, this particular value is obscured by competing 1,2-dehydrohalogenations leading to the gold-containing cations $\mathrm{Au}\left(\mathrm{C}_{2} \mathrm{H}_{4}\right)^{+}$and $\mathrm{Au}(\mathrm{HBr})^{+}$, respectively (Table 3). It is worthwhile to discuss the effect of competition in some

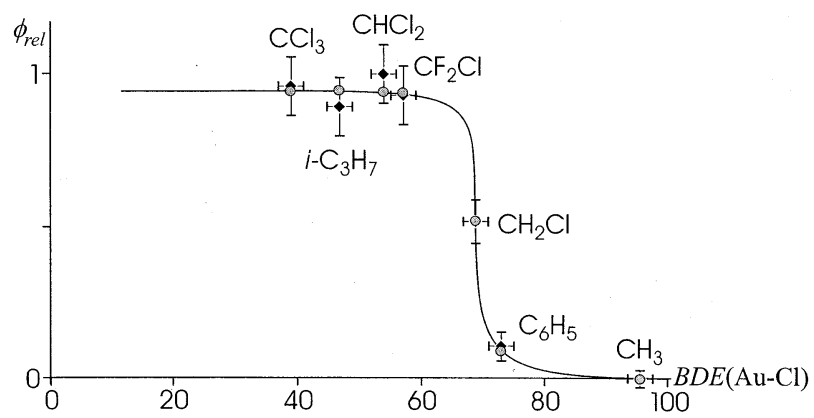

Figure 1. Relative Reaction Efficiencies for Chloride Abstraction from $\mathrm{R}-\mathrm{Cl}$ Compounds by Mass-selected $\mathrm{Au}^{+}$Cations as a Function of the Derived $B D E(\mathrm{Au}-\mathrm{Cl})$. more detail. By definition, ion/molecule reactions cannot proceed faster than the collision limit, such that competing processes may significantly diminish the relative efficiency of the reaction of interest. Taken to the extreme, even thermodynamically and kinetically allowed processes may be suppressed completely, if other, even more favorable pathways can occur. Hence, competition may heavily disturb the thermokinetic method of Bouchoux et al. [31] which relies on overall reaction efficiencies. Note that competition by alternative channels is much less severe in the kinetic method due to Cooks and coworkers [40], where two mutually competing channels are directly compared with each other. In the same manner, one might therefore argue that also bromide abstraction from bromobenzene is masked by the competing electron transfer (see Table 3). Fortunately, however, the reaction of $\mathrm{CF}_{3} \mathrm{Br}$ sets a clear borderline which supports the present analysis. Thus, formation of $\mathrm{CF}_{3}^{+}$from $\mathrm{Au}^{+} / \mathrm{CF}_{3} \mathrm{Br}$ in analogy to eq 1 was only observed when thermalization of $\mathrm{Au}^{+}$was omitted, and under these conditions it ceased at about $8 \%$ conversion with the remaining $\mathrm{Au}^{+}$not reacting at 


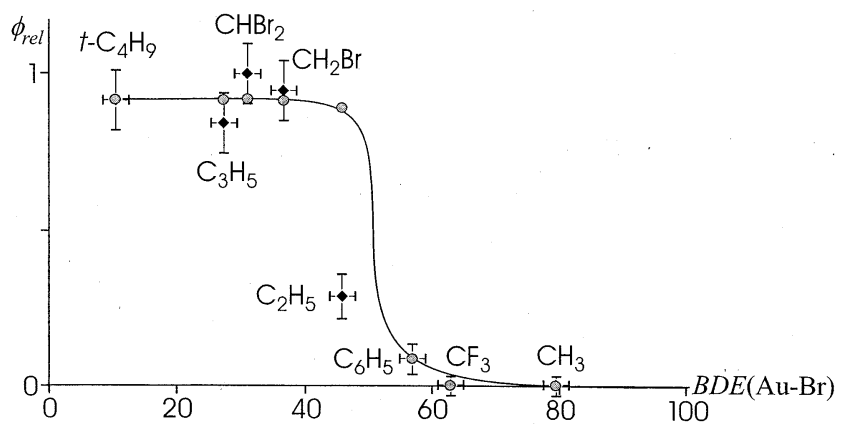

Figure 2. Relative Reaction Efficiencies for Bromide Abstraction from $\mathrm{R}-\mathrm{Br}$ Compounds by Mass-selected $\mathrm{Au}^{+}$Cations as a Function of the Derived $B D E(\mathrm{Au}-\mathrm{Br})$. Note that the entry for $\mathrm{C}_{2} \mathrm{H}_{5} \mathrm{Br}$ is too low due to effectively competing reactions, see text.

all with $\mathrm{CF}_{3} \mathrm{Br}$. Accordingly, formation of neutral $\mathrm{AuBr}$ from the $\mathrm{Au}^{+} / \mathrm{CF}_{3} \mathrm{Br}$ system is assigned as an endothermic process.

Excluding $\mathrm{R}=\mathrm{C}_{2} \mathrm{H}_{5}$ from consideration, the thermokinetic method suggests $B D E(\mathrm{Au}-\mathrm{Br})=53 \pm 4 \mathrm{kcal} / \mathrm{mol}$ where the increased error bar is due to the lack of an intermediate point which also caused the use of the same parameter $\mathrm{b}$ as for $\mathrm{X}=\mathrm{Cl}$ (Figure 2). Accordingly, we arrive at $D_{0}(\mathrm{Au}-\mathrm{Br})=50 \pm 5 \mathrm{kcal} / \mathrm{mol}$ after conversion to $0 \mathrm{~K}$ as described above.

$A u I / A u I^{+}$. Chowdhury and Wilkins [9] already reported that treatment of $\mathrm{Au}^{+}$with iodomethane can be used to generate $\mathrm{AuI}^{+}$cations in the gas phase (eq 2). However, due to the occurrence of the diatomic gold halide as an ionic product, the thermokinetic approach cannot be used unambiguously anymore because the formations of $\mathrm{AuI}$ and $\mathrm{AuI}^{+}$compete for various groups $\mathrm{R}$ (Table 4 ). Of course, the $\mathrm{AuI} / \mathrm{AuI}^{+}$ratio might be used for the determination of $I E(\mathrm{R})$ by means of Cooks' kinetic method [40], but in the present context we are not interested in this quantity. Further, several other reactions take place for the iodine compounds, and hence we have to return to the simple bracketing technique.

$$
\mathrm{Au}^{+}+\mathrm{CH}_{3} \mathrm{I} \rightarrow \mathrm{AuI}^{+}+\mathrm{CH}_{3} \cdot
$$

When thermal contributions are acknowledged, occurrence of eq 2 implies $D_{0}\left(\mathrm{Au}^{+}-\mathrm{I}\right)>54 \mathrm{kcal} / \mathrm{mol}$, while formation of $\mathrm{C}_{6} \mathrm{H}_{5}^{+}$upon reacting $\mathrm{Au}^{+}$with iodobenzene suggests $D_{0}(\mathrm{Au}-\mathrm{I})>40 \mathrm{kcal} / \mathrm{mol}$. However, both processes provide only lower limits. Unfortunately, consideration of consecutive reactions of $\mathrm{AuI}^{+}$does not allow for a refinement of these brackets. For example, the reaction of $\mathrm{AuI}^{+}$with $\mathrm{CH}_{3} \mathrm{I}$ affords an $\left[\mathrm{Au}, \mathrm{C}, \mathrm{H}_{3}, \mathrm{I}\right]^{+}$species with unknown energetics. An upper limit is given by the previously described [41] occurrence of eq 3 under thermal conditions which suggests $D_{0}\left(\mathrm{Au}^{+}-\mathrm{I}\right) \leq D_{0}\left(\mathrm{Au}^{+}-\mathrm{C}_{2} \mathrm{H}_{4}\right) \sim$ $69 \mathrm{kcal} / \mathrm{mol}$.

Table 4. Efficiencies $(\phi \text { in } \%)^{\mathrm{a}}$ and products ${ }^{\mathrm{b}}$ in the reactions of (a) several iodine-containing molecules R-I with mass-selected Au ${ }^{+}$ cations and (b) of arene ligands $\mathrm{L}$ with mass-selected $\mathrm{AuI}^{+}$

\begin{tabular}{|c|c|c|c|c|c|c|}
\hline & $\Delta_{f} H_{298}(\mathrm{R}-\mathrm{X})^{\mathrm{c}}$ & $\phi$ & Products & $\mathrm{Br}^{\mathrm{b}}$ & $\Delta_{f} H_{298}\left(\mathrm{R}^{+}\right)^{\mathrm{c}}$ & $\Delta E_{\text {thermal }}{ }^{\mathrm{d}}$ \\
\hline \multicolumn{7}{|c|}{ (a) $A u^{+}+R-I \rightarrow$ Products } \\
\hline \multirow[t]{5}{*}{$\mathrm{CH}_{3} \mathrm{ef}^{\mathrm{e}}$} & 3.7 & 20 & $\mathrm{Aul}+\mathrm{CH}_{3}^{+}$ & $(0.00)$ & 261 & -1.2 \\
\hline & & & $\mathrm{Aul}^{+}+\mathrm{CH}_{3}$ & $(0.85)$ & & -2.2 \\
\hline & & & $\mathrm{AuCH}_{3}^{+}+\mathrm{I}$ & $(0.10)$ & & -1.0 \\
\hline & & & $\mathrm{AuCH}_{2}^{+}+\mathrm{HI}$ & $(0.01)$ & & \\
\hline & & & $\mathrm{AuH}+\mathrm{CH}_{2} \mathrm{I}^{+}$ & $(0.04)$ & & \\
\hline \multirow[t]{5}{*}{$\mathrm{C}_{2} \mathrm{H}_{5} \mathrm{I}^{+}$} & -2.2 & 56 & $\mathrm{Au}(\mathrm{HI})^{+}+\mathrm{C}_{2} \mathrm{H}_{4}$ & $(0.50)$ & & \\
\hline & & & $\mathrm{Aul}+\mathrm{C}_{2} \mathrm{H}_{5}$ & $(0.20)$ & 216 & -1.6 \\
\hline & & & $\mathrm{Au}\left(\mathrm{C}_{2} \mathrm{H}_{4}\right)^{+}+\mathrm{HI}$ & $(0.10)$ & & \\
\hline & & & $\mathrm{AuH}+\mathrm{C}_{2} \mathrm{H}_{4} \mathrm{I}^{+}$ & $(0.15)$ & & \\
\hline & & & $\mathrm{Au}+\mathrm{C}_{2} \mathrm{H}_{5} \mathrm{I}^{+}$ & $(0.05)$ & & \\
\hline \multirow[t]{4}{*}{$i-\mathrm{C}_{3} \mathrm{H}_{7} \mathrm{I}$} & -9.9 & 79 & $\mathrm{Au}\left(\mathrm{C}_{3} \mathrm{H}_{6}\right)^{+}+\mathrm{HI}$ & $(0.01)$ & & \\
\hline & & & $\mathrm{Aul}+\mathrm{C}_{3} \mathrm{H}_{7}^{+}$ & $(0.60)$ & 191 & -1.8 \\
\hline & & & $\mathrm{H}_{2} / \mathrm{Aul}+\mathrm{C}_{3} \mathrm{H}_{5}^{+}$ & $(0.14)$ & & \\
\hline & & & $\mathrm{Au}+\mathrm{C}_{3} \mathrm{H}_{7} \mathrm{I}^{+}$ & $(0.25)$ & & \\
\hline \multirow[t]{3}{*}{$\mathrm{C}_{6} \mathrm{H}_{5} \mathrm{I}$} & 39.4 & 40 & $\mathrm{Aul}+\mathrm{C}_{6} \mathrm{H}_{5}^{+}$ & $(0.20)$ & 269 & -3.8 \\
\hline & & & $\mathrm{AuC}_{6} \mathrm{H}_{5}^{+}+\mathrm{I}$ & $(0.10)$ & & \\
\hline & & & $\mathrm{Au}+\mathrm{C}_{6} \mathrm{H}_{5} \mathrm{I}^{+}$ & $(0.70)$ & & \\
\hline \multicolumn{7}{|c|}{ (b) $\mathrm{AuI}^{+}+L \rightarrow$ Products } \\
\hline \multirow[t]{2}{*}{$\mathrm{C}_{6} \mathrm{H}_{5} \mathrm{Cl}$} & & & $\operatorname{Aul}\left(\mathrm{C}_{6} \mathrm{H}_{5} \mathrm{Cl}\right)^{+}$ & $(0.30)$ & & \\
\hline & & & $\mathrm{Aul}+\mathrm{C}_{6} \mathrm{H}_{5} \mathrm{Cl}^{+}$ & $(0.70)$ & & \\
\hline \multirow[t]{2}{*}{$\mathrm{C}_{6} \mathrm{H}_{6}$} & & & $\operatorname{Aul}\left(\mathrm{C}_{6} \mathrm{H}_{6}\right)^{+}$ & $(0.80)$ & & \\
\hline & & & $\mathrm{Aul}+\mathrm{C}_{6} \mathrm{H}_{6}^{+}$ & $(0.20)$ & & \\
\hline \multirow[t]{2}{*}{$1,3-\mathrm{C}_{6} \mathrm{H}_{4} \mathrm{~F}_{2}$} & & & $\operatorname{Aul}\left(\mathrm{C}_{6} \mathrm{H}_{4} \mathrm{~F}_{2}\right)^{+}$ & $(0.98)$ & & \\
\hline & & & $\mathrm{Aul}+\mathrm{C}_{6} \mathrm{H}_{4} \mathrm{~F}_{2}^{+}$ & $(0.02)$ & & \\
\hline
\end{tabular}

a-d See footnotes a-d of Table 2.

eWhile the $\left[\mathrm{Au}, \mathrm{C}, \mathrm{H}_{3}, \mathrm{I}^{+}\right.$product reported in Ref. [9] was also observed in our studies, it is attributed to consecutive reactions, see text.

${ }^{\mathrm{f}} \mathrm{A}$ product distribution similar to that reported in Ref. [9] is observed when thermalization of Au ${ }^{+}$by pulsed-in argon buffer gas is omitted. 


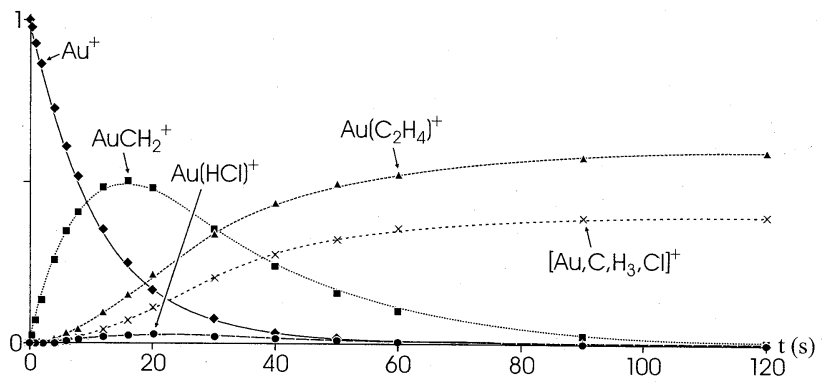

Figure 3. Time dependence of the ionic species in the reaction of mass-selected $\mathrm{Au}^{+}$with chloromethane $\left(p=4 \cdot 10^{-9} \mathrm{mbar}\right)$; dots: experimental data, lines: kinetic fit.

$$
\mathrm{AuI}^{+}+\mathrm{C}_{2} \mathrm{H}_{4} \rightarrow \mathrm{Au}\left(\mathrm{C}_{2} \mathrm{H}_{4}\right)^{+}+I^{\circ}
$$

Note, however, that the experimental estimation of $D_{0}\left(\mathrm{Au}^{+}-\mathrm{C}_{2} \mathrm{H}_{4}\right)$ was inter alia based on eq 3 , and can therefore not serve as an independent reference for the determination of $D_{0}\left(\mathrm{Au}^{+}-\mathrm{I}\right)$. Instead, the value given above refers to several theoretical studies which suggest $D_{0}\left(\mathrm{Au}^{+}-\mathrm{C}_{2} \mathrm{H}_{4}\right)$ between 65 and $75 \mathrm{kcal} / \mathrm{mol}$ [41-43]. Further, in the case of eq 3 the thermal correction due to involvement of an atomic species works in the opposite direction, and accordingly we derive a bracket of 54 $\mathrm{kcal} / \mathrm{mol}<D_{0}\left(\mathrm{Au}^{+}-\mathrm{I}\right)<66 \mathrm{kcal} / \mathrm{mol}$.

In order to gain further insight into the thermochemistry of gold iodide [44], a different strategy was pursued. To this end, cationic $\mathrm{AuI}^{+}$was reacted with neutral arenes $L$ having appropriate ionization energies $I E(\mathrm{~L})$, in order to observe a competition between electron transfer eq $4 \mathrm{a}$ and mere association eq $4 \mathrm{~b}$.

$$
\begin{aligned}
\mathrm{AuI}^{+}+\mathrm{L} & \rightarrow \mathrm{AuI}+\mathrm{L}^{+\cdot} \\
& \rightarrow \operatorname{AuI}(\mathrm{L})^{+}
\end{aligned}
$$

For $\mathrm{L}=$ benzene $(I E=9.24 \mathrm{eV})$, eq $4 \mathrm{~b}$ predominates, whereas electron transfer according to eq 4a prevails for $\mathrm{L}=$ chlorobenzene $(I E=9.07 \mathrm{eV})$. By reference to thermokinetic approaches [31, 40], IE(AuI) $=9.15 \pm 0.1$ $\mathrm{eV}$ is derived accordingly being in certainly fortuitous match with the $\operatorname{CCSD}(\mathrm{T})$ value of $9.18 \mathrm{eV}$. While the association eq $4 \mathrm{~b}$ may obscure electron transfer according to eq $4 a$, the derived figure is further supported by the weakness of eq $4 \mathrm{a}$ with $\mathrm{L}=1,3$-difluorobenzene $(I E=9.33 \mathrm{eV})$ for which also association is much slower than for $\mathrm{L}=\mathrm{C}_{6} \mathrm{H}_{6}$ and $\mathrm{C}_{6} \mathrm{H}_{5} \mathrm{Cl}$. With $\operatorname{IE}(\mathrm{AuI})=9.15 \pm$ $0.1 \mathrm{eV}$ being rather close to $I E(\mathrm{Au})=9.2255 \mathrm{eV}$, it is also concluded that $B D E(\mathrm{Au}-\mathrm{I}) \sim B D E\left(\mathrm{Au}^{+}-\mathrm{I}\right)$ or, more precisely, $52 \mathrm{kcal} / \mathrm{mol}<D_{0}(\mathrm{Au}-\mathrm{I})<64 \mathrm{kcal} / \mathrm{mol}$.

The $\mathrm{Au}^{+} / \mathrm{CH}_{3} \mathrm{Cl}$ system. While we mostly deal with thermochemical aspects of the primary halide abstraction reactions, one particular detail of the consecutive reactions in the $\mathrm{Au}^{+} / \mathrm{CH}_{3} \mathrm{Cl}$ system is worth more detailed consideration. Figure 3 shows the time evolution of the gold-containing product ions upon reacting
$\mathrm{Au}^{+}$with $\mathrm{CH}_{3} \mathrm{Cl}$; for the sake of clarity, minor carbocationic products are omitted (see Table 2). Thus, the gold-carbene cation $\mathrm{AuCH}_{2}^{+}$is formed first in eq $5 \mathrm{a}$, and then $\mathrm{Au}\left(\mathrm{C}_{2} \mathrm{H}_{4}\right)^{+}$as well as $\left[\mathrm{Au}, \mathrm{C}, \mathrm{H}_{3}, \mathrm{Cl}\right]^{+}$are generated which persist with a more or less constant ratio at longer reaction times. Except for a minor channel leading to $\mathrm{Au}(\mathrm{HCl})^{+}$, a more or less superimposable graph has been reported by Chowdhury and Wilkins [9], nicely demonstrating the reproducability of ICR kinetics. Quite different are the interpretations of these data, however, as far as the origin of the $\left[\mathrm{Au}, \mathrm{C}, \mathrm{H}_{3}, \mathrm{Cl}\right]^{+}$ species is concerned. In particular, Chowdhury and Wilkins attributed the formation of $\left[\mathrm{Au}, \mathrm{C}, \mathrm{H}_{3}, \mathrm{Cl}\right]^{+}$cation to a direct association (eq $5 b$ ).

$$
\begin{aligned}
\mathrm{Au}^{+}+\mathrm{CH}_{3} \mathrm{Cl} & \rightarrow \mathrm{AuCH}_{2}^{+}+\mathrm{HCl} \\
& \rightarrow\left[\mathrm{Au}, \mathrm{C}_{2} \mathrm{H}_{3}, \mathrm{Cl}\right]^{+} \\
\mathrm{AuCH}_{2}^{+}+\mathrm{CH}_{3} \mathrm{Cl} & \rightarrow \mathrm{Au}\left(\mathrm{C}_{2} \mathrm{H}_{4}\right)^{+}+\mathrm{HCl} \\
& \rightarrow \mathrm{Au}(\mathrm{HCl})^{+}+\mathrm{C}_{2} \mathrm{H}_{4} \\
& \rightarrow\left[\mathrm{Au}, \mathrm{C}_{3} \mathrm{H}_{3}, \mathrm{Cl}\right]^{+}+\mathrm{CH}_{2} \\
\mathrm{Au}\left(\mathrm{C}_{2} \mathrm{H}_{4}\right)^{+}+\mathrm{CH}_{3} \mathrm{Cl} & \rightarrow\left[\mathrm{Au}, \mathrm{C}_{2} \mathrm{H}_{3}, \mathrm{Cl}\right]^{+}+\mathrm{C}_{2} \mathrm{H}_{4} \\
\mathrm{Au}(\mathrm{HCl})^{+}+\mathrm{CH}_{3} \mathrm{Cl} & \rightarrow\left[\mathrm{Au}, \mathrm{C}_{,} \mathrm{H}_{3}, \mathrm{Cl}\right]^{+}+\mathrm{HCl}
\end{aligned}
$$

Kinetic modeling of the time dependencies of the ionic species is incompatible with eq $5 b$, however, in that $\left[\mathrm{Au}, \mathrm{C}, \mathrm{H}_{3}, \mathrm{Cl}\right]^{+}$is obviously formed in a consecutive reaction. Further, the primary product $\mathrm{AuCH}_{2}^{+}$is unlikely to afford $\left[\mathrm{Au}, \mathrm{C}, \mathrm{H}_{3}, \mathrm{Cl}\right]^{+}$upon reaction with $\mathrm{CH}_{3} \mathrm{Cl}$, because that would require loss of a free $\mathrm{CH}_{2}$ fragment (eq 6c). Therefore, the products generated from $\mathrm{AuCH}_{2}^{+}$are considered next. Equation 6a generates a $\left[\mathrm{Au}, \mathrm{C}_{2}, \mathrm{H}_{4}\right]^{+}$species which is identified as the genuine ethene complex $\mathrm{Au}\left(\mathrm{C}_{2} \mathrm{H}_{4}\right)^{+}$because rapid formation of $\mathrm{Au}\left(\mathrm{C}_{2} \mathrm{D}_{4}\right)^{+}$is observed upon addition of $\mathrm{C}_{2} \mathrm{D}_{4}$ [45]. Formation of $\left[\mathrm{Au}, \mathrm{C}, \mathrm{H}_{3}, \mathrm{Cl}\right]^{+}$via eq 7 can be ruled out, however, because the $\mathrm{Au}\left(\mathrm{C}_{2} \mathrm{H}_{4}\right)^{+}$trace remains constant at longer reaction times though $\mathrm{CH}_{3} \mathrm{Cl}$ is leaked-in continuously and $\mathrm{C}_{2} \mathrm{H}_{4}$ is practically absent, thus suggesting $B D E\left(\mathrm{Au}^{+}-\mathrm{CH}_{3} \mathrm{Cl}\right) \gg B D E\left(\mathrm{Au}^{+}-\mathrm{C}_{2} \mathrm{H}_{4}\right)$ $\approx 69 \mathrm{kcal} / \mathrm{mol}$ [41-43]. Instead, kinetic analysis of the data reveals that formation of $\left[\mathrm{Au}, \mathrm{C}, \mathrm{H}_{3}, \mathrm{Cl}\right]^{+}$can fully be explained by involvement of the $\mathrm{Au}(\mathrm{HCl})^{+}$cation generated in eq $6 b$, even though this product never exceeds a few percent of all ions. In fact, due to its low abundance, Chowdhury and Wilkins might have neglected it as a minor channel. Notwithstanding, formation of $\mathrm{Au}(\mathrm{HCl})^{+}$as a reactive intermediate via eq $6 \mathrm{~b}$ and its depletion in eq 8 can account for the $\left[\mathrm{Au}, \mathrm{C}, \mathrm{H}_{3}, \mathrm{Cl}\right]^{+}$species which contributes to about $40 \%$ of all products at long reaction times. Such a kinetic phenomenon that an "almost invisible" intermediate 


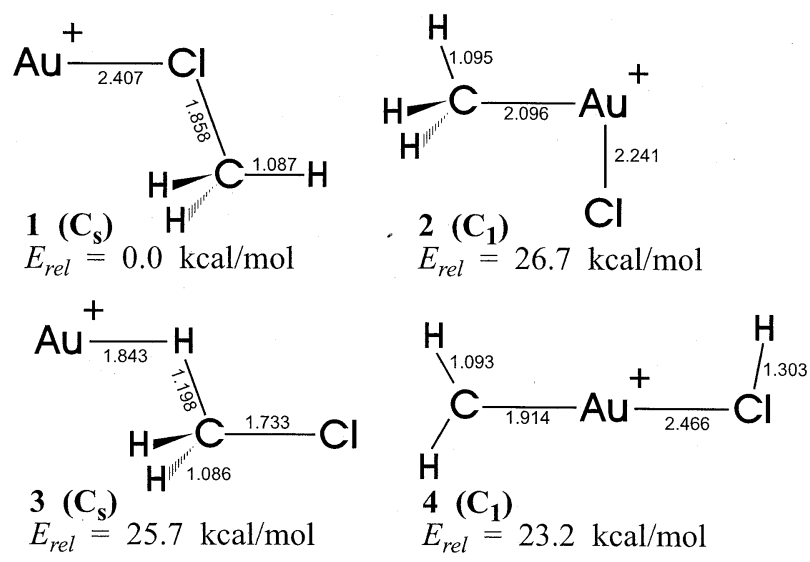

Figure 4. Structures of $\left[\mathrm{Au}, \mathrm{C}, \mathrm{H}_{3}, \mathrm{Cl}\right]^{+}$isomers calculated at the B3LYP/SDD level of theory (selected bond lengths given in $\AA$ ).

determines the outcome of a major pathway in ion/ molecule reactions has been analyzed previously [46], and it can occur if the rate constant for the generation of the intermediate is much lower than those of its consecutive reactions. In the present case, the kinetic fits suggest that $k_{6 b}$ is ca. 18 times lower than $k_{8}$.

$$
\begin{aligned}
& \mathrm{Au}(\mathrm{HCl})^{+}+\mathrm{H}_{2} \mathrm{O} \rightarrow \mathrm{Au}\left(\mathrm{H}_{2} \mathrm{O}\right)^{+}+\mathrm{HCl} \\
& \mathrm{Au}\left(\mathrm{H}_{2} \mathrm{O}\right)^{+}+\mathrm{CH}_{3} \mathrm{Cl} \rightarrow\left[\mathrm{Au}, \mathrm{C}, \mathrm{H}_{3} \mathrm{Cl}\right]^{+}+\mathrm{H}_{2} \mathrm{O}
\end{aligned}
$$

For the sake of completeness, we note that in addition to eq 5-8, also eq 9 and 10 were observed due to the presence of water in the background of the highvacuum system. Accordingly, $\mathrm{D}_{0}\left(\mathrm{Au}^{+}-\mathrm{HCl}\right)<D_{0}\left(\mathrm{Au}^{+}-\right.$ $\left.\mathrm{H}_{2} \mathrm{O}\right) \approx 38 \mathrm{kcal} / \mathrm{mol}[41,42,47,48]$ is implied; our B3LYP calculations predict $D_{0}\left(\mathrm{Au}^{+}-\mathrm{HCl}\right)=30 \mathrm{kcal} /$ mol. This result is by no means unusual as, for example, also the proton affinity of $\mathrm{HCl}$ is significantly lower than that of water [49]. In turn, however, it is fair to ask, why $\mathrm{Au}(\mathrm{HCl})^{+}$is formed at all in eq 6 if ethene is that much a better ligand for ionized gold. A rationale is provided by inspection of the thermochemistry of eq 6 . Thus, with $D_{0}\left(\mathrm{Au}^{+}-\mathrm{CH}_{2}\right) \approx 89 \mathrm{kcal} / \mathrm{mol}$ as suggested by Metz and coworkers [38], formation of the ethene complex $\mathrm{Au}\left(\mathrm{C}_{2} \mathrm{H}_{4}\right)^{+}$in eq $6 \mathrm{a}$ is predicted to be 63 $\mathrm{kcal} / \mathrm{mol}$ exothermic, and eq $6 \mathrm{~b}$ is still exothermic by about $20 \mathrm{kcal} / \mathrm{mol}$. Hence, formation of $\mathrm{Au}(\mathrm{HCl})^{+}$can be attributed to the large amount of energy released upon $\mathrm{C}-\mathrm{C}$ bond formation in the reaction of $\mathrm{AuCH}_{2}^{+}$ with $\mathrm{CH}_{3} \mathrm{Cl}$.

So far, we deliberately used the formula $\left[\mathrm{Au}, \mathrm{C}, \mathrm{H}_{3}, \mathrm{Cl}\right]^{+}$which shall only reflect the elemental composition of the ionic species without any structural specification. In order to gain some structural insight, several conceivable $\left[\mathrm{Au}, \mathrm{C}, \mathrm{H}_{3}, \mathrm{Cl}\right]^{+}$species were examined by means of exploratory B3LYP calculations (Figure 4). The association complex $\mathbf{1}$ with gold attached to the chlorine atom corresponds to the most stable species $\left(E_{\text {rel }}=0.0 \mathrm{kcal} / \mathrm{mol}\right)$. Three other isomers are located ca. $25 \mathrm{kcal} / \mathrm{mol}$ higher in energy and correspond to the
$\mathrm{C}-\mathrm{Cl}$ bond insertion species 2, the ion/dipole complex with gold binding to one of the hydrogen atoms 3 , and the carbene complex 4 . Despite some uncertainty in the level of theory used, it is quite safe to assume that isomer $\mathbf{1}$ is formed in the $\mathrm{Au}^{+} / \mathrm{CH}_{3} \mathrm{Cl}$ system. This conclusion fully confirms the previous assignment of structure $\mathbf{1}$ by Chowdhury and Wilkins, based on the observation that $\left[\mathrm{Au}, \mathrm{C}, \mathrm{H}_{3}, \mathrm{Cl}\right]^{+}$undergoes ligand exchange to yield $\mathrm{AuL}^{+}$and neutral $\mathrm{CH}_{3} \mathrm{Cl}$ when reacted with benzene and acetonitrile, respectively [9]. At the B3LYP level of theory, $D_{0}\left(\mathrm{Au}^{+}-\mathrm{CH}_{3} \mathrm{Cl}\right)$ is computed as $42 \mathrm{kcal} / \mathrm{mol}$ which is consistent with the significantly larger affinities of gold to benzene and acetonitrile, respectively [41, 42]. Finally, also the occurrence of eq 10 is consistent with structure $\mathbf{1}$ as well as $D_{0}\left(\mathrm{Au}^{+}-\right.$ $\left.\mathrm{CH}_{3} \mathrm{Cl}\right)>D_{0}\left(\mathrm{Au}^{+}-\mathrm{H}_{2} \mathrm{O}\right) \approx 38 \mathrm{kcal} / \mathrm{mol}[41,42,47,48]$.

\section{Conclusions}

Guided by theoretical studies, experimental measurements of gold halides lead to an improved set of $B D E s$ for neutral gold(I) halides as well as the $\mathrm{AuI}^{+}$, cation, i.e, $D_{0}(\mathrm{Au}-\mathrm{Cl})=66 \pm 3 \mathrm{kcal} / \mathrm{mol}, D_{0}(\mathrm{Au}-\mathrm{Br})=50 \pm 5$ $\mathrm{kcal} / \mathrm{mol}$, as well as the brackets $52 \mathrm{kcal} / \mathrm{mol}<$ $D_{0}(\mathrm{Au}-\mathrm{I})<64 \mathrm{kcal} / \mathrm{mol}$, and $54 \mathrm{kcal} / \mathrm{mol}<D_{0}\left(\mathrm{Au}^{+}-\mathrm{I}\right)<$ $66 \mathrm{kcal} / \mathrm{mol}$ at $0 \mathrm{~K}$. With respect to the previous experimental and theoretical data (Table 1), the following conclusions can be drawn. (i) The earlier experimental data of Chowdhury and Wilkins [9] are fully consistent with the present results. (ii) Inclusion of entropy effects is essential for a quantitative analysis of ion/molecule reactions when an atomic species is involved on only one side of the reaction. (iii) The values derived from vibrational spectroscopy are somewhat overestimated. (iv) Most of the computational approaches slightly underestimate the bond strengths.

Despite of the improved accuracy of the present experiments, the error margins are still considerable, and further refinement would be desirable. In particular, the fact that $D_{0}(\mathrm{Au}-\mathrm{Br})$ is at the lower limit of $D_{0}(\mathrm{Au}-\mathrm{I})$, though within the error margins, appears surprising. Further, it needs to be stressed that the thermokinetic methods used here crucially rely on the accuracy of the auxiliary thermochemistry used for anchoring, and changes in the heats of formation of the carbocationic species involved would, of course, also affect the derived $B D E s(\mathrm{Au}-\mathrm{X})$.

\section{Acknowledgments}

Financial support by the Deutsche Forschungsgemeinschaft, the Fonds der Chemischen Industrie, the Gesellschaft von Freunden der Technischen Universität Berlin, and the Degussa-Hüls AG is gratefully acknowledged. The Konrad-Zuse Zentrum, Berlin, is appreciated for generous allocation of computer time. JRB and PS are grateful to the Marsden Fund (Wellington) for financial support. 


\section{References}

1. Pyykkö, P. Chem. Rev. 1988, 88, 563.

2. Hargittai, M.; Schulz, A.; Réffy, B.; Kolonits, M. J. Am. Chem. Soc. 2001, 123, 1449.

3. Evans, C. J.; Gerry, M. C. L. J. Am. Chem. Soc. 2000, 122, 1560.

4. Andreev, S.; BelBruno, J. J. Chem. Phys. Lett. 2000, 329, 490.

5. O'Brien, L.-C.; Ellito, A. L.; Dulick, M. J. Mol. Spectrosc. 1999, 194, 124.

6. Evans, C. J.; Gerry, M. C. L. J. Mol. Spectrosc. 2000, 203, 105.

7. Evans, C. J.; Lesarri, A.; Gerry, M. C. L. J. Am. Chem. Soc. 2000, $122,6100$.

8. Reynard, L.; Evans, C. J.; Gerry, M. C. L. J. Mol. Spectrosc. 2001, $205,344$.

9. Chowdhury, A. K.; Wilkins, C. L. J. Am. Chem. Soc. 1987, 109, 5336.

10. Schröder, D.; Hrušák, J.; Tornieporth-Oetting, I. C.; Klapötke, T. M.; Schwarz, H. Angew. Chem. 1994, 106, 223 ; Angew. Chem. Int. Eng. Ed. 1994, 33, 212.

11. Schwerdtfeger, P.; McFeaters, J. S.; Stephens, R. L.; Liddell, M. J.; Dolg, M.; Hess, B. A. Chem. Phys. Lett. 1994, 218, 362.

12. Schwerdtfeger, P.; McFeaters, J. S.; Liddell, M. S.; Hrušák, J.; Schwarz, H. J. Chem. Phys. 1995, 103, 245.

13. Schwerdtfeger, P. Mol. Phys. 1995, 86, 359.

14. Iliaš, M.; Furdík, P.; Urban, M. J. Phys. Chem. A 1998, 102, 5263.

15. van Wüllen, C. J. Chem. Phys. 1998, 109, 392.

16. Schwerdtfeger, P.; Dolg, M.; Schwarz, W. H. E.; Bowmaker, G. A.; Boyd, P. D. W. J. Chem. Phys. 1989, 91, 1762.

17. Schwerdtfeger, P.; Boyd, P. D. W.; Brienne, S.; Burrell, A. K. Inorg. Chem. 1992, 31, 3411.

18. Eller, K.; Zummack, W.; Schwarz, H. J. Am. Chem. Soc. 1990, $112,621$.

19. Bartmess, J. E.; Georgiadis, R. M. Vacuum 1983, 33, 149.

20. Schröder, D.; Schwarz, H.; Clemmer, D. E.; Chen, Y.-M.; Armentrout, P. B.; Baranov, V. I.; Böhme, D. K. Int. J. Mass Spectrom. Ion Processes 1997, 161, 177.

21. Su, T. J. Chem. Phys. 1988, 89, 5355 , and references therein.

22. Gaussian 98, Revision A.7, M. J. Frisch, G. W. Trucks, H. B. Schlegel, G. E. Scuseria, M. A. Robb, J. R. Cheeseman, V. G. Zakrzewski, J. A. Montgomery, Jr., R. E.Stratmann, J. C. Burant, S. Dapprich, J. M. Millam, A. D. Daniels, K. N. Kudin, M. C. Strain, O. Farkas, J. Tomasi, V. Barone, M. Cossi, R. Cammi, B. Mennucci, C. Pomelli, C. Adamo, S. Clifford, J. Ochterski, G. A. Petersson, P. Y. Ayala, Q. Cui, K. Morokuma, D. K. Malick, A. D. Rabuck, K. Raghavachari, J. B. Foresman, J. Cioslowski, J. V. Ortiz, A. G. Baboul, B. B. Stefanov, G. Liu, A. Liashenko, P. Piskorz, I. Komaromi, R. Gomperts, R. L. Martin, D. J. Fox, T. Keith, M. A. Al-Laham, C. Y. Peng, A. Nanayakkara, C. Gonzalez, M. Challacombe, P. M. W. Gill, B. Johnson, W. Chen, M. W. Wong, J. L. Andres, C. Gonzalez, M. Head-Gordon, E. S. Replogle, and J. A. Pople, Gaussian, Inc., Pittsburgh PA, 1998.

23. Schwerdtfeger, P.; Brown, R.; Laerdahl, J. K.; Stoll, H. J. Chem. Phys. 2000, 113, 7110.
24. Andrae, D.; Haeussermann, U.; Dolg, M.; Stoll, H.; Preuss, H. Theor. Chim. Acta 1990, 77, 123.

25. Dunning, T. H., Jr. J. Chem. Phys. 1989, 90, 1007.

26. Woon, D. E.; Dunning, T. H., Jr. J. Chem. Phys. 1993, 98, 1358.

27. Schwerdtfeger, P.; Boyd, P. D. W. Inorg. Chem. 1992, 31, 327.

28. Bergner, A.; Dolg, M.; Kuechle, W.; Stoll, H.; Preuss, H. Mol. Phys. 1993, 80, 1431.

29. K. Andersson, M. R. A. Blomberg, M. P. Fülscher, V. Kellö, R. Lindh, P.-Å. Malmqvist, J. Noga, J. Olsen, B. O. Roos, A. J. Sadlej, P. E. M. Siegbahn, M. Urban, and P. O. Widmark, Program VIBROT, implemented in MOLCAS, Version 2, University of Lund, Sweden, 1991.

30. Moore, C. E. Atomic Energy Levels, Natl. Bur. Stand. (US), Circ. No.; 467. US GPO: Washington, DC, 1958.

31. Bouchoux, G.; Leblanc, D.; Sablier, M. Int. J. Mass Spectrom 2001, 210/211, 189 , and references cited therein.

32. Martin, W. C.; Musgrove, A. http://physics.nist.gov/PhysRefData/IonEnergyhttp://physics.nist.gov/PhysRefData/ IonEnergy.

33. Vasile, M. J.; Richardson, T. J.; Stevie, F. A.; Falconer, W. E. J. Chem. Soc. Dalton Trans. 1976, 4, 351.

34. Chilingarov, N. S.; Korobov, M. V.; Rudometkin, S. V.; Alikhanyan, A. S.; Sidorov, L. N. Int. J. Mass Spectrom. Ion Processes 1986, 69, 175

35. Gmelin Handbook, Au Suppl. Vol. B1, p. 125.

36. Saenger, K.; Sun, C. P. Phys. Rev. A 1992, 46, 670.

37. Unless mentioned otherwise, all thermochemical data are taken from:Lias, S. G.; Bartmess, J. E.; Liebman, J. F.; Holmes, J. L.; Levin, R. D.; Mallard, W. G. Gas Phase Ion and Neutral Thermochemistry. J. Phys. Chem. Ref. Data Suppl. 1), 17.

38. Aguirre, F.; Husband, J.; Thompson, C. J.; Metz, R. B. Chem. Phys. Lett. 2000, 318, 466.

39. Schröder, D.; Loos, J.; Schwarz, H.; Thissen, R.; Dutuit, O. Inorg. Chem. 2001, 40, 3161.

40. For a recent review, see: Cooks, R. G.; Wong, P. S. H. Acc. Chem. Res. 1998, 31, 379.

41. Schröder, D.; Hrušák, J.; Hertwig, R.H.; Koch, W.; Schwerdtfeger, P.; Schwarz, H. Organometallics 1995, 14, 312.

42. Hertwig, R. H.; Hrušák, J.; Schröder, D.; Koch, W.; Schwarz, H. Chem. Phys. Lett. 1995, 236, 194.

43. Hertwig, R. H.; Koch, W.; Schröder, D.; Schwarz, H.; Hrušák, J.; Schwerdtfeger, P. J. Phys. Chem. 1996, 100, 12253.

44. Also see: Söhnel, T.; Brown, R.; Kloo, L.; Schwerdtfeger, P. Chem. Eur. J. 2001, 7, 3167.

45. Schröder, D.; Wesendrup, R.; Hertwig, R. H.; Dargel, T.; Grauel, H.; Koch, W.; Bender, B. R.; Schwarz, H. Organometallics 2000, 19, 2608.

46. Schwarz, J.; Schröder, D.; Schwarz, H.; Heinemann, C.; Hrušák, J. Helv. Chim. Acta 1996, 79, 1110.

47. Hrušák, J.; Schröder, D; Schwarz, H. Chem. Phys. Lett. 1994, $225,416$.

48. Feller, D.; Glendening, E. D.; de Jong, W. A. J. Chem. Phys. 1998, 110, 1475.

49. Hunter, E. P. L.; Lias, S. G. J. Phys. Chem. Ref. Data 1998, $27,413$. 